\title{
REVIEW OF CRIMINAL CASES IN MARYLAND BY HABEAS CORPUS AND BY APPEAL
}

\section{Charles Markell $\dagger$}

Until comparatively recent changes, the Maryland practice in habeas corpus proceedings and also in criminal appeals was unusual as compared with practices in other jurisdictions. Since 1941, constitutional and statutory changes and judicial decisions have eliminated or mitigated evils of the earlier methods. Changes in the two fields, however, were made without apparent regard for each other; consequently any relation to, or effect upon, each other seems to be "purely coincidental." The purpose of this paper is briefly to describe the old practices and the changes made, and to indicate their value or effect.

\section{Habeas Corpus}

" "The writ of habeas corpus is a high prerogative writ, given by the common law, and made effective and enforced by statute, the great object of which is the liberation of parties who may be imprisoned or detained without sufficient cause.' State v. Glenn. . . . It is perhaps the most important writ known to the constitutional law of England, affording as it does a swift and imperative remedy in all cases of illegal restraint or confinement. It is of immemorial antiquity, an instance of its use occurring in the thirty-third year of Edward I.' Secretary of State for Home Affairs v. O'Brien [1923] A. C. 603, 609." 1

The present Maryland constitution (of 1867) provides: "The General Assembly shall pass no law suspending the privilege of the writ of habeas corpus." 2 "What constitutes the privilege of the writ . . . whether it be the right to it as defined by law at the adoption of the constitution, or whether it be according to the practice of any subsequent legislature, however restricted that privilege may be, may admit of serious question." 3 This constitutional provision "is not a prohibition of further legislation reasonably regulating the issuance of the

$\dagger$ A.B., Johns Hopkins University; LL.B., University of Maryland. Chief Judge of Maryland Court of Appeals, retired, 1952.

1. Olewiler v. Brady, 185 Md. 341, 345, 44 A.2d 807, 809 (1951).

2. Mo. Const., Art. III, §55.

3. State v. Glenn, 54 Md. 572, 596 (1880). 
writ." 4 Although the English habeas corpus act ${ }^{5}$ has not been in force in Maryland since the Revolution, it was substantially reenacted, with some changes, in the Maryland Act of 1809; one of the changes was omission of a requirement of prepayment of the charges of bringing the prisoner. ${ }^{6}$

In Maryland habeas corpus procedure prior to 1941 , two practices persisted: (1) a common (but not universal) practice (not expressly required by statute or judicial decisions) to issue the writ as a matter of course, and (2) the absence of any general right of appeal, by either party.

The practice of issuing the writ as a matter of course may have been the result of two provisions of the earlier habeas corpus statutes, both of which originated in analogous provisions of the English act. The Act of 1880 provided:

"Any person committed, detained, confined or restrained from his lawful liberty within this State for any alleged offense, or under any color or pretense whatsoever, or any person in his or her behalf may complain to the court or judge having jurisdiction and power to grant the writ of habeas corpus, to the end that the cause of such commitment, detainer, confinement or restraint may be inquired into; and the said respective courts or judges to whom such complaint is so made shall forthwith grant the writ of habeas corpus, directed to the officer or other person in whose custody or keeping the party so detained shall be, returnable immediately before the said court or judge granting the same." 7

Section 15 of the same act provided: "If any judge, whether in court or out of court, shall refuse any writ of habeas corpus by this article required to be granted, he shall be liable to the action of the party aggrieved." 8

“. . . for many years before 1941 it was common practice in Maryland to issue the writ of habeas corpus as a matter of course. This practice led to growing abuse. Eventually, for some years, the writ was habitually perverted from its great object, and became a device whereby a convicted prisoner could obtain intermission of imprisonment through excursions to distant counties at public expense. The practice became a recognized evil. The legislature by the Act of 1941, Chapter 484 and the Act of 1945, Chapter 702 undertook to remedy the evil." 9

4. Olewiler v. Brady, supra note 1 at 346,44 A.2d at 809.

5. 31 CAR. II, c. 2 (1679).

6. Olewiler v. Brady, supra note 1 at 346,44 A.2d at 809 .

7. MD. CODE PUB. GEN. LAWS art. $42, \S 3$ (1888) (Italies added in part).

8. Id. $\$ 15$ (This section became $\$ 14$ in the later codes).

9. Olewiler v. Brady, supra note 1 at 347,44 A.2d at 810 . 
The Act of 1941 repealed section 14 (which made the judge liable in tort) and amended section 3 so that the judge is required to issue the writ, ". . . unless it appears from the complaint itself or the doctments annexed that the petitioner would not be entitled to any relief. "10 By chapter 702 of the Act of 1945 it was expressly provided that the judge might dismiss the petition or require it to be amended or otherwise amplified unless the application alleges facts sufficient, if true, to probably show that the applicant is illegally detained. ${ }^{11}$ The result of the changes in Maryland practice is:

"The writ of habeas corpus is a writ of right; it did not, however, at common law or under the statute of 31 Car. II, issue as of course, but on probable cause for it being shown. Secretary of State for Home Affairs $v$. O’Brien, supra, 1923 A. C. 618. Opinion on the Writ of Habeas Corpus, Wilm. 77, 81-94. . . .

"..

"Whether, by the general language of Sections 3 and 14 of Article 42 of the Code of 1939 and the corresponding sections of the Code of 1860 and the intervening legislation, judges were required to issue the writ of habeas corpus as of course, is a question which it is not necessary to consider. If they were, any such requirement has been removed, and the practice in this respect under the more restricted language of the statute of 31 Car. II and the Act of 1809 has been restored, by amendment of Section 3 and repeal of Section $14^{4}$ by the Act of 1941 and enactment of Section 3B by the Act of 1945." 12

In so restoring the early English and Maryland practice, Maryland conformed with practice in this respect which is now apparently universal.

\section{Appeal in Habeas Corpus}

The absence of any general right of appeal ${ }^{13}$ in habeas corpus cases was in accord with the early English practice and with general

10. Md. Ann. Code Pub. Gen. Laws art. 42, 3 (Flack 1951).

11. Md. Ann. Code Pub. Gen. Laws art. 42, $\$ 5$ (Flack 1951).

12. Olewiler v. Brady, supra note 1 at $346,347-8,44$ A.2d at 809,810 (footnote omitted).

13. The Act of 1880, Chapter 6, provided a special right of appeal from an order releasing or discharging a party on habeas corpus upon the ground of the unconstitutionality of the statute which he was charged with violating. This provision is still in force, MD. ANN. CODE PUB. GEN. LAwS art. 42, $\$ 19$ (Flack 1951), but it has been superseded by the broader provisions for appeal in the Act of 1945-and an act of 1947. According to tradition-or ancient gossip-this provision for a limited appeal was prompted by the fact that one circuit judge was effecting jail delivery on a large scale throughout the state by releasing on habeas corpus persons convicted (or charged with) petty statutory offenses before justices of the peace, on the ground that such statutes were unconstitutional as denying the right of trial by jury. Promptly after passage of the Act of 1880, on an appeal thereby authorized, it was held that such statutes do not violate the constitutional provision for trial by jury. State v. Glenn, 54 Md. 572 (1880). 
construction of statutes relating to appeals or writs of error. An order discharging or remanding a prisoner on habeas corpus is not appealable to the Court of Appeals ${ }^{14}$ as a final judgment in a civil suit; it "is not final and conclusive upon the party applying for the writ; as he may prefer a similar application, to any other judge or court of the State." ${ }^{15}$ In 1923 the House of Lords applied the old rule that an order discharging a prisoner from custody on habeas corpus is not reviewable on appeal or writ of error by the prosecution unless such review is expressly authorized by statute; and further held that general statutory authority to review orders of the lower court was not such express authority. ${ }^{16}$ The facts that statutory authorizations to the Court of Appeals of Maryland empowering it to grant writs of habeas corpus were held unconstitutional ${ }^{17}$ and that no general right of appeal existed, resulted in almost a complete dearth of authoritative case law on the subject of habeas corpus. Until 1945, practically all the case law was to be found in the opinion in State v. Glenn. ${ }^{18}$

The Act of 1945 provided that the "aggrieved" applicant might appeal to the Court of Appeals from refusal to issue the writ or from a final order remanding him or dismissing the proceedings and that the Attorney General or the State's Attorney might appeal on behalf of the state. ${ }^{19}$ The general right of appeal under the Act of 1945 was equally applicable to the petitioner and the state. However, the nature of habeas corpus procedure makes it, in operation, one-sided against the prosecutors. Before 1945, the petitioner in effect had the right of 36 appeals by applications to every other judge in the state. One judge might set at naught the judgment of 36 other judges by releasing on habeas corpus a prisoner whom the other judges would not release. The petitioner still has 36 such appeals besides an appeal to the Court of Appeals.

By the Act of 1947, the statute was amended to substitute for a right of appeal a right "to apply to the Court of Appeals . . . for leave to prosecute an appeal therefrom." 20 This amendment apparently was intended to lighten the duties of the Court of Appeals in connection

14. The Court of Appeals is the highest appellate court in Maryland.

15. Bell v. State, 4 Gill. 301, 304 (Md. 1846). See also Matter of Coston, 23 Md. 271 (1865); Coston v. Coston, 24 Md. 500, 506 (1866).

16. Secretary of State for Home Affairs v. O'Brien, [1923] A.C. 603.

17. Under the constitution of 1851, which expressly provided that "the Court of Appeals shall have appellate jurisdiction only" Ex. parte O'Neill, 8 Md. 227 (1855) and under the constitution of 1867 , which does not expressly so provide, Sevinskey v. Wagus, $76 \mathrm{Md}$. 335, 336, 25 Atl. 468 (1892). Surprisingly, the Code of 1951 provides: "The court of appeals . - shall have the power to grant the writ of habeas corpus. . . MD. ANN. Code PUB. GeN. LAws art. 42, \$1 (Flack 1951).

18. $54 \mathrm{Md} .572$ (1880).

19. Acts of 1945, c. $702, \S 3 \mathrm{C}$.

20. Ibid. 
with habeas corpus appeals, but in practice the only change in the great majority of cases is that the disposition is "application denied," instead of "order affirmed."

The Maryland constitution provides that "in every case an opinion, in writing, shall be filed" ${ }^{21}$ by the Court of Appeals. For practical purposes, denial of application for leave to appeal, no less than affirmance on appeal, finally disposes of "a case"; 22 any distinction in this respect would seem to be a palpable evasion of the constitutional requirement, and to defeat any value there may be in the right of appeal in habeas corpus cases. Accordingly, on denial of application for leave to appeal in a habeas corpus case, an opinion (usually brief) is filed just as was done on affirmance under the Act of 1945. When (in rare instances) leave to appeal is granted, no opinion is filed until on appeal the case is disposed of in regular course.

The requirement of written opinions, combined with the general right of appeal of 1945 (and now the right to apply for leave to appeal) has resulted in the development of an authoritative body of case law on the subject of habeas corpus. One aspect of this law merits a brief discussion.

In Price v. Clazens, 23 the court quoted United States Supreme Court cases ${ }^{24}$ as apparently holding that in case of conviction under an unconstitutional statute the court is without jurisdiction and the sentence is therefore a nullity. On the basis of these same cases some jurisdictions have held that a conviction and sentence thus obtained may be attacked on habeas corpus, even though the case may be fully reviewable on appeal. In later cases ${ }^{25}$ the United States Supreme Court has held that the judgment of a superior court of general jurisdiction ${ }^{26}$ is not a nullity, and ordinarily will be reviewed only on appeal and not on habeas corpus. With respect to convictions for federal offenses, the federal courts have discretionary power (exercised in exceptional cases not clearly defined) to review on habeas corpus, convictions under unconstitutional statutes and other cases which might have been reviewed on appeal. ${ }^{27}$

21. Mp. Const., Art. IV, $\S 15$.

22. The statute expressly provides that the effect shall be the same. Mo. ANn. CODE PUb. GeN. LAws art. 42, § 6. (Flack 1951).

23. 180 Md. 532, 535, 24 A.2d 672, 674 (1942).

24. Ex parte Yarborough, 110 U.S. $651,653-4$ (1884) ; Ex parte Siebold, 100 U.S. 371,376 (1879).

25. Sunal v. Large, 332 U.S. 174, 177-82; Bowen v. Johnston, 306 U.S. 19, 26-7 (1939); Glasgow v. Moyer, 225 U.S. 420,429 (1912); Loughran v. Warden, 192 Md. $719,724-5,64$ A.2d 712, 715, cert. denied sib nom. Loughran v. Maryland, 337 U.S. 908 (1949).

26. In some jurisdictions the rule has been stated and applied without restriction to such courts. Yutze v. Copelan, 109 Ohio St. 171, 142 N.E. 33 (1923). In Maryland this question has never been passed upon.

27. See Loughran v. Warden, note 25 supra. 
Two features of the almost 200 habeas corpus cases disposed of by the Court of Appeals since 1945 may be noted: (1) the scope and application of the rule that habeas corpus cannot, unless by statute, be used as an appeal or new trial, and (2) the applicability of habeas corpus for the protection of some of the rights held by recent United States Supreme Court decisions to be essentials of "due process."

In Olewiler $v$. Brady, ${ }^{28}$ the court quoted (a) from State $v$. Glemn, ${ }^{29}$ the general rule in the former class of cases, and (b) from recent Supreme Court decisions, an apparent exception to this rule in the latter class.

" "The writ of habeas corpus cannot be made, unless it be by express statute, to perform the functions of a writ of error, in bringing under review a judgment or sentence of a competent tribunal, simply for errors or irregularities in the proceedings, or in the rendition of the judgment or sentence; that must be done by some more direct and appropriate proceeding.' State v. Glenn, $54 \mathrm{Md}$. 572, 608. Cf. Johnson v. Zerbst, 304 U. S. 458, 465, 82 L. Ed. 1461. Still less can habeas corpus be used to review the verdict of a jury on disputed facts. 'An imprisonment, under a sentence by a Court or magistrate of competent jurisdiction, is not unlawful, unless the sentence, for some cause to be made apparent, be not merely erroneous but an absolute nullity; though if it be shown to be such nullity, the party is entitled to his immediate discharge.' State v. Glenn, supra; Cf. Price v. Clawns, $180 \mathrm{Md}$. 532, 534-537, 25 A. 2d 672. Recent Supreme Court cases hold that through violation of certain constitutional rights in criminal procedure a trial court may lose its jurisdiction 'in the course of the proceedings' and its judgment may therefore be void. Johnson v. Zerbst, supra, 304 U. S. 468, 82 L. Ed. 1461 ; Smith v. O'Grady, 312 U. S. 329, 334, 85 L. Ed. 859; Betts v. Brady, 316 U. S. 455, 86 L. Ed. 1595 ; Williams v. Kaiser, 323 U. S. 471, 65 S. Ct. 363." 30

In footnote 2 the court states:

"In some circumstances 'the use of the writ in the federal courts to test the constitutional validity of a conviction for crime is not restricted to those cases where the judgment of conviction is void for want of jurisdiction of the trial court to render it. It extends also to those exceptional cases where the conviction has been in disregard of the constitutional rights of the accused, and where the writ is the only effective means of preserving his rights.' Waley v. Johnson, 316 U. S. 101, 105, 62 S. Ct. 964, 966, 86 L. Ed. 1302." 31

28. See note 1 supra.

29. See note 3 supra.

30. Olewiler v. Brady, note 1 supra, at $344-45,44$ A.2d at 808 .

31. Id. at $345, \mathrm{n} .2,44 \mathrm{~A} .2 \mathrm{~d}$ at $808, \mathrm{n} .2$. 
Later the exceptional cases were mentioned, not in terms of "lack of jurisdiction" or "loss of jurisdiction", but as depending upon violation of fundamental rights which prevents resort to appeal and therefore justifies resort to habeas corpus-an apparent, not a real, exception to the basic rule. "In exceptional cases where fundamental rights have been violated in the course of the trial, and such violation has not only resulted in conviction, but has likewise prevented resort to the remedy of appeal, the writ of habeas corpus may be the only effective means of preserving such rights." 32

In this respect the rule that habeas corpus cannot be made to serve as an appeal or new trial is less qualified in Maryland than it is in the federal courts-or apparently in the numerical majority of other jurisdictions where the point has been passed upon. ${ }^{33}$ In State $v$. Glenn, ${ }^{34}$ and in State ex rel. Byrd v. Warden ${ }^{35}$ the judgments of conviction under attack were judgments not of superior courts of general jurisdiction, but of justices of the peace. On habeas corpus (or application for it) it was held that the statutes were constitutional and the judgments of the justices of the peace therefore were not void.

The great majority of the 200 cases disposed of by the Court of Appeals have been disposed of on the ground that habeas corpus cannot be used as an appeal or new trial. Other cases that could have been so disposed of were decided by holding untenable the points of criminal law or procedure raised. Most of these cases have little basis except the applicant's dissatisfaction with his confinement. They are prosecuted without counsel and probably would not be undertaken by any lawyer. It seems appropriate that, whenever possible, these cases be disposed of on the ground that habeas corpus is not a proper remedy, and not by passing upon questions of criminal law or procedure without benefit of argument of counsel.

Exceptional cases, in which violation of fundamental rights has prevented resort to appeal and habeas corpus is the only means of preserving such rights, include cases of pleas of guilty, waiver of counsel or jury trial obtained by coercion ${ }^{36}$ and use of perjured testimony by connivance of state's officers. ${ }^{37}$ In Maryland the remedy of writ of error coram nobis is recognized, within common law limits. ${ }^{38}$ It has not been, as it has been in some states from which cases have reached

32. Loughran v. Warden, note 25 supra, at 724-5.

33. See cases collected in Note, 167 A.L.R. 522-7, 527-9 (1947).

34. 54 Md. 572, 596 (1880).

35. 191 Md. 670, 62 A.2d 628 (1948).

36. Cases cited in Loughran v. Warden, note 25 supra.

37. Mooney v. Holohan, 294 U.S. 103 (1935).

38. Keane v. State, 164 Md. 685, 166 Atl. 410 (1933); Bernard v. State, 193 Md. 1, 65 A.2d 297 (1949). 
the United States Supreme Court, so expanded or so vaguely stated as to make it difficult or impossible to say whether habeas corpus or coram nobis is the proper remedy. As held by the United States Supreme Court, it is recognized in Maryland that jurisdiction on habeas corpus (though it has seldom been so exercised in Maryland) extends to exceptional cases in which violation of fundamental rights has prevented resort to appeal.

Review of Maryland habeas corpus cases by the United States Supreme Court is perhaps simplified by the fact that, as a result of the constitutional requirement, a written opinion is filed in each case. The brief opinions in most of these cases make no marked contribution to the literature of the law, but they do furnish an articulate statement of the legal nature of each case and the ground of decision. No habeas corpus case in the Court of Appeals has yet been reviewed by the United States Supreme Court on certiorari. When application is made for certiorari, the opinion of the Court of Appeals of Maryland at least prevents the embarrassment which confronts the Supreme Court (since, as well as before, passage of the Illinois Post-Conviction Hearing Act), ${ }^{39}$ in hundreds of Illinois cases. These latter cases were cases decided below without opinion, in which the United States Supreme Court was required to dispose of the preliminary question of whether the prisoner had performd his duty "to ride the Illinois merry-goround" 40 of remedies before resorting to a federal court. Cases from Illinois are by no means the only cases which present the embarrassment of decisions below with no opinion.

By the Act of 1945 it is provided that whenever it appears that the applicant has previously been granted a hearing on a prior application for release from confinement under the same commitment, it shall be discretionary with the judge whether or not to issue the writ; in exercising his discretion the judge may consider whether new grounds of a substantial nature appear to exist or whether the grounds for issuance of any former writ were fully and adequately presented. ${ }^{41}$ The Court of Appeals has recognized this statutory provision, ${ }^{42}$ but has seldom mentioned it and has never construed it. In most of the habeas corpus cases that have reached the Court of Appeals, the application was preceded by one or more (sometimes many) previous applications which had been denied. As the testimony and proceedings at habeas corpus hearings usually are not stenographically recorded, and before 1941 petitions for habeas corpus usually were expressed in general

39. Jennings v. Illinois, 342 U.S. 104 (1951).

40. Marino v. Ragen, 332 U.S. 561, 570 (1951).

41. Mo. ANn. Code Pur. Gen. Laws, art. 42, 44 (Flack 1951).

42. State ex rel. Harris v. Warden, 195 Md. 702, 72 A.2d 713 (1950). 
terms and disclosed no specific facts, a hearing judge has had little opportunity, and the Court of Appeals less, to ascertain the grounds of former applications or whether they were fully and adequately presented. The Act of 1947 now provides: "The judge in refusing to issue, or denying, or granting any writ shall file a substantial but succinct statement, either in writing or by dictation to the stenographer for the court records, setting forth the grounds of the application, the questions involved, and the reasons of the Court for the action taken." 43 These statements, even if sufficient on appeal, might not be adequate for comparison with subsequent applications. Consequently, when an application is denied, the judge, and on appeal the Court of Appeals, usually have shown that on its face the present application is inadequate without regard to previous applications.

"Assuming, without deciding, that notwithstanding the Act of 1945, ch. 702, Art. 42, sec. 3A, Code 1947 Supplement, the doctrine of res judicata does not extend to a decision on habeas corpus . . . , nevertheless such a decision is not without weight on a later application." 44 A decision which is not res judicata is nonetheless binding under the doctrine of stare decisis. In the Court of Appeals some of the unsuccessful applicants have successively appealed, or asked leave to appeal, from denials of successive applications. In such cases the brief opinions of the Court of Appeals are generally briefer than usual, consisting of a statement that no new grounds are alleged. One of these applicants has made seven applications for leave to appeal, ${ }^{45}$ and two applications to the United States Supreme Court for certiorari. ${ }^{46}$ The statute provides, "The Court of Appeals may permit an appeal to be prosecuted without the prior payment of costs." 47 The Act of 1945 expressly authorized the court to "permit a hearing on the original papers" ${ }^{48}$ and by a rule of court, pursuant to the Act of 1947 , this is now done in all habeas corpus cases. ${ }^{49}$ Thus even the deterrent of costs is inoperative against this kind of repetitious or otherwise futile litigation.

The results and the evident purposes of the Acts of 1941 and 1945 have been to put an end to long-standing abuse of the writ and to pre-

43. Mo. Ann. Code Pub. Gen. Laws art. 42, $\$ 5$ (Flack 1951).

44. State ex rel. Eyer v. Warden, 190 Md. 767, 772, 59 A.2d 745, 747 (1948); citing Salinger v. Loisel, 265 U.S. 224, $230-2$ (1924).

45. Holliday v. Warden, 190 Md. 732, 59 A.2d 777 (1947); 191 Md. 763, 62 A.2d 573 (1948); 195 Md. 706, 72 A.2d 684 (1950); 80 A.2d 32 (Md. 1951); 80 A.2d 608 (Md. 1951); 81 A.2d 56 (Md. 1951) ; 84 A.2d 697 (Md. 1951).

46. 336 U.S. 928 (1949) ; 339 U.S. 971 (1950).

47. Mo. Ann. Code Pub. Gen. Laws, art. 42, §6 (Flack 1951).

48. Acts of 1945 , c. $702, \S 3 \mathrm{C}$.

49. Mo. Ann. Code Pub. Gen. Laws, Rules of the Court of Appeals, Rule 50 (Flack 1951); see Mo. Ann. Cone Pub. Gen. Laws, art. 42, §6 (Flack 1951). 
serve the writ for its historic objects as a bulwark of liberty. This has been done by abolishing the general (though not universal) practice of issuing the writ as a matter of course, without any showing of need for it, and by giving a general right of appeal, thus substituting authoritative statements of the law for the action of 37 judges, of equal authority, not subject to review by any higher court. The right of appeal, given without prepayment of costs, is as freely available to either party as the writ itself.

\section{Criminal Appeals}

By Criminal Rules of Practice and Procedure, effective January 1, $1950,{ }^{50}$ and by a constitutional amendment ratified in 1950,51 more change was made, in law if not in practice, in criminal appellate procedure than was made in habeas corpus procedure by the recent legislation on that subject. In general, the effect was to broaden the scope of review by appeal. It is not the purpose of this paper to discuss at large the subject of criminal appeals. Jurisdiction on habeas corpus does not depend upon the adequacy, inadequacy or even the existence of a remedy by appeal in a particular case. If the relief sought is appropriate on appeal, and not on habeas corpus, habeas corpus will not be granted, even though the particular case, or the particular question, e.g., legal sufficiency of the evidence, ${ }^{52}$ is not or was not reviewable on appeal. Nevertheless, as the applicability of a remedy by appeal (or motion for a new trial), if any, ordinarily bars a remedy by habeas corpus, it seems pertinent to note the two outstanding changes in criminal appeals.

The Maryland constitution of 1867 , like the constitutions of 1851 and 1864, provided "In the trial of all criminal cases, the jury shall be the Judges of Law, as well as of fact." 53

In 1858 the Court of Appeals held that this provision "is merely declaratory, and has not altered the pre-existing law regulating the powers of the court and jury in criminal cases" and does not "authorize the jury to judge of the constitutionality of [an] Act of Assembly." 54 Ever since the controversy that culminated in the passage of Fox's Libel Act ${ }^{55}$ the question had been mooted whether in criminal cases the jury are rightfully "the judges of law as well as of fact." This

50. Md. Ann. Code Pub. Gen. Laws, $4885-4890$ (Flack 1951).

51. Wright v. State, 81 A.2d 602 (Md. 1951).

52. See text at note 58 infra.

53. Mo. Const., Art. XV, $\$ 5$ (1867).

54. Franklin v. State, 12 Md. 236, 245-6, 249 (1858).

55. 32 GEo. III, c. 60 (1792). 
question was whether the power of the jury to find a general verdict of not guilty and the lack of power of the court to direct a verdict of guilty amounted to a right of the jury to decide questions of law as well as questions of fact. In the United States Supreme Court this question was finally decided in the negative (two justices dissenting) in 1895. ${ }^{56}$ The Maryland constitutional provision soon ceased to be (if it ever was) declaratory of pre-existing law. In 1876, at least, it ceased to be declaratory when it was held that on account of this constitutional provision the judge cannot be required to instruct the jury on the law in a criminal case. ${ }^{57}$ The constitutional provision was carried to the full logical extreme of holding that the Court of Appeals could not review the legal sufficiency of the evidence to convict. ${ }^{58}$ A conviction "in spite of the absolute failure of legal evidence to justify a conviction" was reversed, not for this reason, but for exclusion of evidence tending to show innocence. ${ }^{59}$ Only this last logical step in the application of the constitutional provision was repealed by the constitutional amendment of 1950. This amendment added to the provision making the jury the judges of law as well as fact, the words, "except that the Court may pass upon the sufficiency of the evidence to sustain a conviction."

The two outstanding features of Maryland criminal appellate procedure were (and to a lesser degree still are): (1) the constitutional provision that "the jury shall be judges of law, as well as of fact," and (2) the fact that in Maryland from early times the constitutional right of trial by jury could be waived by the accused, even in capital cases. ${ }^{60}$ Trial without a jury long antedated statutory authority, but since 1793 has been expressly authorized by statute. "Any person presented or indicted may, instead of traversing the same before a jury, traverse the same before the court, who shall thereupon try the law and the facts." "11 Construing this statute, it was said, "The effect of this is to allow a party the privilege of electing to be tried by the Court instead of a jury, and when such election is made, the Court is substituted for the jury, and has the same duties and functions to perform in passing

56. Sparf v. United States, 156 U.S. 51 (1895).

57. Broll v. State, 45 Md. 356, 359-60 (1876).

58. Bloomer v. State, 48 Md. 521 (1878) ; Abbott v. State, 188 Md. 310, 313, 52 A.2d 489, 496 (1947).

59. O'Brecht v. State, 145 Md. 171, 176, 125 Atl. 539, 541 (1924).

60. In Baltimore (and probably elsewhere throughout the state) upwards of 95\% of all criminal cases are tried without a jury; Bond, The Maryland Practice of Trying Criminal Cases by Judges Alone, Without Juries, 11 A.B.A.J. 699 (1925).

61. MD. ANn. Code Pub. Gen. Laws art. 27, $\$ 678$ (Flack 1951). The editor of the Code of 1951 accurately states in a footnote that the words above italicized have been "superseded by Rule 7 of the Criminal Rules of Practice and Procedure of the Court of Appeals. . " Cf. 2 LAws of MD. c. 57 (Kilty 1793) ; 4 Laws of MD. c. 144, §2 (Kilty 1809); Mv. Code GeN. Laws art. 30, §91 (1860). 
upon the guilt or innocence of the accused." 02 Pursuing this reasoning, it was held that in a case tried without a jury, as in jury cases, the Court of Appeals could not review the legal sufficiency of the evidence to convict. ${ }^{63}$

"By Section 5, Article 15 of the Constitution of this State, it is distinctly provided that in the trial of all criminal cases, the jury shall be the judges of law as well as of fact," [sic] and in a number of cases in this Court from Franklin v. State, 12 Md. 236, to Luery v. State, $116 \mathrm{Md}$. 292, it has been repeatedly held that the Court has the right to advise the jury in a criminal case, although it is not bound and cannot be required to do so. If the instruction however given be erroneous and the jury have followed it to the plain injury of the traverser though in a mere advisory form, it may be made the subject of an exception and corrected on appeal. Luery v. State, 116 Md. 292; Esterline v. State, 105 Md. 636; Dick v. State, 107 Md. 11; Swan v. State, 64 Md. 423; Guy v. State, 96 Md. 699; Beard v. State, 71 Md. 275." 64

Before adoption of the Criminal Rules of Practice and Procedure, the Court of Appeals, both in jury cases and in non-jury cases, could not review the facts, the legal sufficiency of the evidence or the refusal to grant an advisory instruction; but it could review the correctness of advisory instructions actually given. In practice criminal appeals were ordinarily confined to rulings on pleadings and on admissibility of evidence.

In 1953 -or 1933 - the reasoning in League $v$. State, ${ }^{65}$ and the structure of corollaries and analogies built on it seem quaint and artificial. In the light of history, however, the view that in non-jury cases the court was substituted for the jury and performed the same functions-not subject to review on appeal-was the basis of non-jury trials in Maryland, both in civil and criminal cases, in state and federal courts. The essential difference between the old and the new procedure in this respect is the difference between "the court sitting as a jury" and "the court sitting without a jury."

Section 18A of Article 4 of the Maryland constitution (added by a constitutional amendment ratified in 1944), provides: "The Court of Appeals from time to time shall make rules and regulations to regulate and revise the practice and procedure in that Court and in the other courts of this State, which shall have the force of law until rescinded, changed or modified by the Court of Appeals or otherwise

62. League v. State, $36 \mathrm{Md}$. 257, 265 (1872) (Italics added).

63. Abbott v. State, 188 Md. 310, 313-314, 52 A.2d 489, 490-491 (1947).

64. Cochran v. State, 119 Md. 539, 552, 87 Atl. 400, 405 (1913).

65. $36 \mathrm{Md} .257$ (1880). 
by law." Section 18 of the original constitution of 1867 made a similar provision for rules for courts of equity only. In both jury and non-jury cases, before action under the rule-making power, the same limitations upon appellate review had resulted, directly or indirectly, from the constitutional provision-in jury cases directly, in non-jury cases indirectly by analogy in the construction of the statute. In nonjury cases these limitations were subject to the rule-making power and were accordingly abolished by a rule which makes such cases fully reviewable both on the law and on the facts. ${ }^{68}$ In jury cases the rulemaking power is subject to the constitutional provision that the jury is trier of the facts and the law and could not override it. The scope of appellate review was broadened in jury cases (before the adoption of the constitutional amendment of 1950) by making it the duty, as well as the right, of the trial judge, when properly requested, to give advisory instructions, either that the evidence is legally insufficient to convict or on any material question of law. ${ }^{67}$ It is not anticipatedand it has not been found-that juries are likely to pay any less attention to advisory instructions than to binding instructions. Aside from the logical absurdity of instructing a jury as to the law and then telling them that they need pay no attention to the instruction, an advisory instruction (which is all that the constitution permits) serves the same practical purpose as a binding instruction. Absurd or not, the right and power of the jury to disregard the instructions of the court was all that was meant by the historic contention that (without express constitutional provision to the contrary) the jury was the judge of law as well as fact. ${ }^{68}$ After the adoption of the criminal rules the constitutional amendment of 1950 made an instruction that evidence is legally insufficient to sustain a conviction binding, instead of advisory. Rule 6 was amended accordingly.

Non-jury cases are made fully reviewable on both the law and the facts by Rule 7, which is similar to (though not the same as) the corresponding Rule 9 of the rules applicable to civil cases, ${ }^{69}$ and to the

66. Mo. General Rules of Practice and Procedure, Criminal Rule 7 (Flack 1951) (trial by court).

67. Mo. General Rules of Practice and Procedure, Criminal Rule 6 (Flack 1951) (advisory instructions to jury).

68. Georgia v. Brailsford, 3 Dall. 1, 4 (Pa. 1794).

69. "Rule 9. Trial by the Court.

“.. .

"(c) . . U Upon appeal the Court of Appeals may review upon both the law and the evidence, but the judgment of the trial court shall not be set aside on the evidence, unless clearly erroneous, and due regard shall be given to the opportunity of the trial court to judge the credibility of the witnesses. " MD. GENERAL RULes OF PRACTICE ANd PRocedure, LAW Rule 9 (Flack 1951). 
corresponding Rule 52 (a) of the Federal Rules of Civil Procedure, ${ }^{70}$ viz., "Rule 7. Trial by the Court. (c) . . . Upon appeal the Court of Appeals may review upon both the law and the evidence to determine whether in law the evidence is sufficient to sustain the conviction, but the verdict of the trial court shall not be set aside on the evidence, unless clearly erroneous, and due regard shall be given to the opportunity of the trial court to judge of the credibility of the witnesses." 71 If "sufficient" meant only "legally sufficient," review on appeal would apparently be limited to the legal sufficiency of the evidence and not to ultimate questions of fact when the evidence is conflicting. This, however, would make the reference to credibility of witnesses meaningless. It has been held that review of the evidence is not so limited on appeal. ${ }^{72}$ Since, in criminal cases perhaps more than in civil cases, findings of fact depend largely on credibility of witnesses, a finding of fact on evidence will rarely be reversed on appeal. No such case has yet occurred.

". . In any case, civil or criminal, to meet the test of legal suffciency, evidence (if believed) must either show directly, or support a rational inference of, the fact to be proved. In a civil case the fact must be shown, or the inference supported, by a preponderance of probability or an opposite preponderance must be overcome. In a criminal case the fact must be shown, or the inference supported, beyond a reasonable doubt or to a moral certainty. . . . The difference in degree of proof is ordinarily for the triers of facts." 78 "This Court will not in a jury case pass upon the weight of the evidence or decide whether the State has proved its case beyond a reasonable doubt. If there is any proper evidence before the jury on which to sustain a conviction, the motion for a directed verdict will not be granted." 74 The only "proper" evidence on which to sustain a conviction is evidence on which, if believed, a jury of reasonable men could (but not necessarily would) find guilt beyond a reasonable doubt. Ordinarily this measure is applied by the jury. But when the court holds the evidence legally sufficient to convict, it does not do so because (as has repeatedly been said in civil cases), "A prayer seeking to take a case from the jury for a want of

70. "Rule 52. ...

(a) ... Findings of fact shall not be set aside unless clearly erroneous, and due regard shall be given to the opportunity of the trial court to judge the credibility of the witnesses. . " FED. R. CIV. P. 52.

71. Mo. General Rules of Practice and Procedure, Criminal Rule 7 (Flack 1951).

72. Edwards v. State, 83 A.2d 578, 579 (Md. 1951); Diggins v. State, 84 A.2d 845 (Md. 1951).

73. Edwards v. State, supra note 72 at 581.

74. Yanch v. State, 93 A.2d 749, 751-752 (Md. 1953). 
legally sufficient evidence will not be granted if there is any evidence, however slight [or however weak], ${ }^{75}$ legally sufficient as tending to prove it-that is to say, competent, pertinent, and coming from a legal source-but the weight and value of such evidence will be left to the jury." 78 To direct a verdict of not guilty it is not sufficient that the evidence, if believed, leaves a reasonable doubt in the mind of the court (trial judge or appellate court); this is a question for the jury, not for the court. To direct a verdict the court must be able to say that the evidence must leave a reasonable doubt in the mind of any reasonable man. ${ }^{77}$

In different jurisdictions, sometimes in the same jurisdiction, the function of the court in directing a verdict of not guilty has been differently stated. Much of the conflict between such statements is more apparent than real. In the Feinberg case in 1944 the Circuit Court of Appeals for the Second Circuit, in an opinion by Judge Learned Hand, said: “ . . . courts-at least federal courts-have generally declared that the standard of evidence necessary to send a case to the jury is the same in both civil and criminal cases; and that given evidence from which a reasonable person might conclude that the charge in an indictment was proved, the court will look no farther, the jury must decide, and the accused must be content with the instruction that before finding them guilty they must exclude all reasonable doubt." The court expressed agreement with an eighth circuit opinion which "refused to distinguish between the evidence which should satisfy reasonable men, and the evidence which should satisfy reasonable men beyond a reasonable doubt. While at times it may be practicable to deal with these as separate without unreal refinements, in the long run the line between

75. Davis v. Barney, 2 Gill. \& J. 382 (Md. 1830).

76. Hodges v. Baltimore Engine Co., 126 Md. 307, 314, 94 Atl. 1040, 1043 (1915) Baltimore v. Carroll, 128 Md. 68, 71-72, 96 Atl. 1076, 1077 (1916); Taxicab Co. of Baltimore v. Emanuel, 125 Md. 246, 259, 93 At1. 807, 813 (1915); Universal Credit Co. v. Merryman, 173 Md. 256, 262-263, 95 Atl. 689, 692 (1937) ; Standard Accident \& Life Ins. Co. v. Wood, 116 Md. 575, 588, 82 Atl. 702, 705-6 (1911); Metropolitan Life Ins. Co. v. Neikirk, 175 Md. 163, 173, 200 Atl. 370, 375 (1938); Gohlinghorst v. Metropolitan Life Ins. Co., $177 \mathrm{Md}$ d 157, 161-162, 8 A.2d 919, 921 (1939); Atholwood Development Co. v. Houston, 179 Md. 441, 445, 19 A.2d 706, 708 (1941); Miller v. Moose Lodge No. 358, 179 Md. 530, 535, 20 A.2d 156, 158 (1941); Weil v. Lambert, 183 Md. 233, 243, 37 A.2d 312, 316 (1944); State v. Carroll-Howard Supply Co., 183 Md. 293, 300, 37 A.2d 330, 334 (1944) ; Crunkilton v. Hook, 185 Md. 1, 5-6, 42 A.2d 517, 519 (1945) ; Levin v. Cook, 186 Md. 535, 541, 47 A.2d 505, 508 (1946); East Coast Freight Lines v. Baltimore, $190 \mathrm{Md}$. 256, 272, 58 A.2d 290, 297 (1948); York Motor Express Co. v. State, 195 Md. 525, 532, 74 A.2d 12, 15 (1950); and many other cases. This oft-repeated description of legally sufficient evidence is not a definition because, as a definition, it would make a complete circle. "Legally sufficient evidence is any evidence, however slight, that is legally sufficient." But by whatever other adjectives qualified, "evidence, however slight," as a matter of law falls short of "proper evidence" of guilt beyond a reasonable doubt or to a moral certainty.

77. Curley v. United States, 160 F.2d 229, 232-235 (D.C. Cir. 1946), cert. denied, 331 U.S. 837 (1947). 
them is too thin for day to day use." 78 Within five years after the Feinberg case the court for the Second Circuit in seven cases (the opinions in four by Judge Learned Hand) cited the Feinberg case as holding that the standard of evidence necessary to send a case to the jury is the same in both civil and criminal cases. ${ }^{79}$ In what is apparently the only case in any other court in which the Feinberg case has been cited on this point, a district judge in California found "an apparent conflict between" the Feinberg case and the Curley ${ }^{80}$ case, but concluded that "the 'true rule' of the Curley case and the 'standard of evidence' set up in the Feinberg case are found after analysis to be one and the same. . . . Both are obviously intended to clarify the oft-stated requirement that there must be 'substantial evidence' of guilt to warrant submission of the case to the jury." 81 Probably in effect, though not in words, the multitude of Maryland cases hold that, in both civil and criminal cases, evidence, to be legally sufficient, must be "substantial." It is so held in terms with respect to the findings of various administrative bodies; it has not been suggested that juries have

78. United States v. Feinberg, 140 F.2d 592, 594 (2d Cir.), cert. denied, 322 U.S. 726 (1944). The full discussion on this point is as follows: "As we understand it, the accused do not argue that the evidence would not have supported a verdict in a civil case, but they do say that it was not cogent enough to exclude all reasonable doubt of their guilt. Evidence upon an issue which merely preponderates is indeed different from evidence which excludes all doubt; and the same tenderness which imperatively requires the customary admonition to a jury, might also have resulted in a straiter scrutiny of the evidence in a prosecution than in a civil suit, before the issues should be presented to a jury. United States v. Renda, 2 Cir., 56 F.2d 601 . Courts have sometimes expressed themselves as though there were a difference. Fraina v. United States, 2 Cir., 255 F. 28, 35; Chicco v. United States, 4 Cir., 284 F. 434 ; Lempie v. United States, 9 Cir., $39 \mathrm{~F} .2 \mathrm{~d}$ 19. It is probable, whatever they say, that in their actual judgments the added gravity of the consequences often makes them more exacting. But courts-at least federal courts-have generally declared that the standard of evidence necessary to send a case to the jury is the same in both civil and criminal cases; and that, given evidence from which a reasonable person might conclude that the charge in an indictment was proved, the court will look no further, the jury must decide, and the accused must be content with the instruction that before finding him guilty they must exclude all reasonable doubt. Pierce v. United States, 252 U.S. 239, 251, 252, 40 S. Ct. 205, 64 L.ed. 542; Matthews v. United States, 8 Cir., 192 F. 490, 494, 495; Stout v. United States, 8 Cir., 227 F. 799, 801 ; Hays v. United States, 8 Cir., 231 F. 106, 108, affirmed sub nom. Caminetti v. United States, 242 U.S. 470, 37 S. Ct. 192, 61 L.ed. 442, L.R.A. 1917F, 502, Ann. Cas. 1917B, 1168; Looker v. United States, 2 Cir., 240 F. 932; Felder v. United States, 2 Cir., 9 F.2d 872, 875; United States v. Rowe, 2 Cir., 56 F.2d 747, 750, 751 ; Crono v. United States, 9 Cir., 59 F.2d 339. We agree with Judge Amidon in Hays v. United States, supra, 231 F. 106, who refused to distinguish between the evidence which should satisfy reasonable men, and the evidence which should satisfy reasonable men beyond a reasonable doubt. While at times it may be practicable to deal with these as separate without unreal refinements, in the long run the line between them is too thin for day to day use."

79. United States v. Andolshek, 142 F.2d 503, 504-505 (2d Cir. 1944); United States v. Pape, 144 F.2d 778, 781 (2d Cir. 1944); United States v. Cohen, 145 F.2d 82, 86 (2d Cir. 1944) ; United States v. Picirelli, 148 F.2d 997, 998 (2d Cir. 1945) ; United States v. Greenstien, 153 F.2d 550, 551 (2d Cir. 1946); United States v. Spagnuolo, 168 F.2d 768, 770 (2d Cir. 1948); United States v. Sherman, 171 F.2d 619, 621 (2d Cir. 1948).

80. See note 77 supra.

81. United States v. Schneiderman, 106 F. Supp. 906, 920 (S.D. Cal. 1952). 
any greater legal or constitutional right to substitute conjecture for proof than the "special juries of experts" who make up administrative bodies. "Any evidence, however slight," or "however weak," not only involves reasoning in a circle, but is incomplete. There must be some evidence, "beyond a mere scintilla," 82 or a surmise or conjecture. So long as "any evidence, however slight" is used to describe legally sufficient evidence in a civil case, the same words cannot be used in both civil and criminal cases. Even if in both civil and criminal cases "substantial evidence" is required, substantial evidence to show a fact is not the same thing as substantial evidence to show guilt beyond a reasonable doubt. In the New York Court of Appeals it is common practice to reverse a judgment of conviction in a jury case "on the ground that the evidence is insufficient in law to warrant a finding of guilt beyond a reasonable doubt." ${ }^{83}$ Unless this is sheer tautology, it recognizes, without analyzing, the difference between evidence legally sufficient to warrant a finding of a fact and evidence legally sufficient to warrant a finding of guilt beyond a reasonable doubt.

The results and the evident purposes of the recent habeas corpus legislation in Maryland have been to put an end to long standing abuse of the writ and to preserve the writ for its historic objects as a bulwark of liberty. The decisions that habeas corpus can be used to perform the function of a writ of error or appeal only in the event that the trial involved a denial of "due process" or other fundamental rights and destruction of the right of appeal in the particular case seem in accord with sound reasoning if not with the numerical weight of authority in other jurisdictions. In any event written opinions have furnished an articulate body of case law on habeas corpus. The right of appeal, given without prepayment of costs, is as freely available as the writ itself.

The changes in criminal appellate procedure, by rules of court and by constitutional amendment, have no special reference to habeas corpus cases as such, and no special effect in such cases-unless perhaps to diminish any temptation to make exceptions to the rule that habeas corpus cannot be used as an appeal or new trial. These changes

82. Baltimore Transit Co. v. State, 184 Md. 250, 259, 40 A.2d 678, 684 (1945); State v. P.W. \& B. R.R., 47 Md. 76, 87 (1877) ; Baltimore \& P.R.R. v. State, 54 Md. 648, 656 (1880) ; B. \& O. R.R. v. State, 71 Md. 590, 599, 18 Atl. 969, 971 (1889); Annapolis \& S. I. R.R. v. Pumphrey, 72 Md. 82, 85, 19 At1. 8, 9 (1890); Baltimore v. War, 77 Md. 593, 604, 27 Atl. 85, 88 (1893); Riley v. N.Y. P. \& N. R.R., 90 Md. 53, 58, 44 Atl. 994, 996 (1899) ; B. \& O. R.R. v. Black, 107 Md. 642, 661, 69 Atl. 439, 446 (1908); Consolidated Gas, Electric Light \& Power Co. v. Smith, 109 MId. 186, 210, 72 Atl. 651, 660 (1909).

83. People v. Moscarelli, 303 N.Y. 923, 55 N.E.2d 754 (1952); People v. Carpenito, 292 N.Y. 498, 55 N.E.2d 754 (1944) ; People v. Richardson, 287 N.Y. 563, 38 N.E.2d 227 (1941); cf. Curley v. United States, 160 F.2d 229, 232-235 (D.C. Cir. 1946), cert. denied, 331 U.S. 837 (1947). 
in the constitutional provision that "the jury shall be the judges of law, as well as of fact" and in practice based, by statute or judicial decisions, on analogy to the constitutional provision have gone far to cure anomalies in the former criminal appellate procedure. These changes, far reaching as they are, are only a part of the extensive changes (not here discussed at large) effected by the criminal rules of procedure. 